\title{
Benefits of Co-curricular and Extracurricular Activities to the Marginalized Children: Social Welfare Residential Educational Institutions
}

\section{Bollam Karunakar}

Research Scholar, Dr. B.R. Ambedkar Open University, Hyderabad, India

Corresponding author: karnab123@gmail.com

Received: 10-04-2020 Revised: 20-06-2020

Accepted: 25-07-2020

\begin{abstract}
This article explores co-curricular and extra-curricular activities and benefits in Telangana Social Welfare Residential Educational Institutions. This paper describes the activities and benefits to students against the background of acquisition of skills for the 21st century. Teachers and students of residential schools are working day and night with a dedication to catapult the Society to the global map within six years. The society schools carved a niche for itself by its seamless experimentation and syncing with the emerging trends in the education space. The Residential schools are committed for the overall social, physical, educational and emotional well-being of the students. TSWREIS has brought out the academic calendar with a comprehensive framework on curricular and Co-Curricular and student-centric programs. Co-curricular and Extra-curricular activity may have an important role to play in the health and well-being of students. Many new academic programs, both co-curricular and extra-curricular activities were incorporated into the academic calendar and promoting a unique teaching and learning environment which empowers students. The residential campus life is vibrant, and the students benefit from a comprehensive range of curricular, co-curricular and extra-curricular activities. The Society has introduced programs like Saturday Clubs, Language, DEAR Time, Diary Writing, Mirror project, Healthy Tuesdays, DEAP Time, Dramatics, Mock Programs, School garage, Community Out Reach Programs, Swatch Saturday, School museum, Moot Court, Mock Election and Youth Parliament. This study adopted a descriptive survey method to analyze the data collected through interviews and questionnaires from teachers and students and found there is a significant development in education achievement, cultural values and personality development.
\end{abstract}

Keywords: Quality Education, Co-curricular activities, Extra-curricular Activities, Marginalized children, Residential School

Telangana Social Welfare Residential Educational Institutions Society (TSWREIS) under preservation of the Ministry of Scheduled Caste Development, Government of Telangana, has been passionately working to place the poorest among the Scheduled Castes in the prosperous orbit through quality education for the last 35 years. This Society is providing quality education in English medium up to graduation. The mission of the residential schools is to promote a wide range of curricular and extra-curricular programs beyond the confines of classrooms to create a spirited teaching and learning environment and help marginalized students realize their full potential in every sphere of life in the $21^{\text {st }}$ century. There is a total of 268 residential, educational institutions from 5th standard to Undergraduate level to 149680 students of the total 268 institutions. Academic

\footnotetext{
How to cite this article: Karunakar, B. (2020). Benefits of Co-curricular and Extracurricular Activities to the Marginalized Children: Social Welfare Residential Educational Institutions. Educational Quest: An Int. J. Edu. Appl. Soc. Sci., 11(2): 43-51.
}

Source of Support: None; Conflict of Interest: None 
calendar designed to discover hidden powers of the students in academics, sports, cultural activities, and promote creativity, innovation, scientific temper, and leadership and communication skills among students. The Society almanack designed to promote the spirit of adventure, scientific temper, creativity and leadership and help students face the challenges of the fast-changing world.

The Sustainable Development Goals are a collection of 17 goals designed to be a blueprint for achieving a better and more sustainable future for all. And set by the United Nations General Assembly and intended to be achieved by the year 2030. Residential Schools are striving for providing quality education, and it is the foundation for improving people's lives and sustainable development (Goal 4: Quality Education). The TSWREIS is making an effort to reduce inequalities by paying attention to the needs of disadvantaged and marginalized populations (Goal 10: Reduced Inequalities).

The Society introduced many path-breaking initiatives which are aimed at nurturing students' potential in co-curricular and extra-curricular activities. In the Academic Calendar, strict instructions are included in the job chart of RCO/ DCO/ Principal/ Teacher/ Special Teacher/ PD/PET for better implementation of co-curricular and extracurricular activities.

\section{Review of Related Literature}

The Gurukul system of education came into existence since ancient times in India. The Social Welfare Residential Educational Institutional Society schools are also called as Gurukulam Schools. Residential schools are giving most importance to co-curricular activities and extra-curricular activities in the academic calendar along with integrated curriculum for all-round development of students. These activities develop social skills, personality progress, intellectual skills, moral values, and character appeal in students. Mr Akunuri Naresh, an alumnus of social welfare residential school, Narsampet, Warangal and social welfare residential junior college, IIT Nagole chased his most cherished dream of becoming an Indian civil servant and secured 782 ranks in the highly prestigious and competitive UPS Exam (2019) on his third attempt.

The study of literature provides insight and guidance in the collection of the objectives of the work. According to (Mohanty, 2015) revealed that due to the residential environment, creative pedagogy, and various co-curricular activities, the residential school children were found to be more creative than formal school students. There were some significant positive correlations found among information processing skills and creative thinking dimensions.

A study by (Dikshit, 2017) concluded that participation of secondary school boys in cocurricular activities and inculcation of moral values is associated with each other. (Eraiah, 2016) observed that positive correlation was found among $9^{\text {th }}$ standard students in residential and nonresidential schools concerning attitude towards cocurricular activities and self-concept. (Prakash, 2008) results concluded that the secondary school students are showing a high positive attitude towards the co-curricular activities.

Abreo 2003, reported that significant positive and very high correlation was found between the academic achievement of the schools at Class $X$ Board Examination and the co-curricular activities conducted by the schools. (Simoncini \& Caltabiono, 2012) their study investigated the relationship between behaviour and participation in extracurricular activities in children aged between five and eight years. Participation, number of activities, and duration of activities were all associated with children's behaviour. Children who participated in extra-curricular activities had lower behaviour scores than those who did not. The results suggest that children benefit from participating in two or more activities for 80-90 minutes per week. (Clariana et al. 2014) study results indicate that both the type of extra-curricular activity and the number of years doing it, and also the level of academic procrastination perceived by the parents, show clear differentiated signs between girls and boys.

Additionally, male students improve in terms of academic procrastination reported by their parents after four years' experience in extra-curricular sports activities; in contrast, girls have greater control over academic procrastination perceived by their parents after four years of extra-curricular artistic activities. (Behtoui, 2019) along with the family, the peer group and the school environment, extra-curricular activities are important contexts for young people's educational and social development. This article 
is the result of a survey conducted with a sample of young people in their last year of compulsory school in Sweden and examines both who has access to the different types of extra-curricular activity and the consequences of their participation in the various programmes. As the results indicate, after controlling for respondents' class and migrant background, their gender and their health, there are positive and significant associations between participation in certain types of activity (sporting, cultural and religious findings of the study show that class background and family resources are, indeed, the crucial factors explaining the disparity in youngsters' opportunities to participate in organized leisure activities. Young people from more-privileged social-class backgrounds are much more likely to attend these programs. (Siddiky, 2019) the study found that the students have developed an extensive range of personal and social skills including communication skill, presentation skill, public speaking skill, organizing skill, and analytical skill by taking part in co-curricular and extracurricular activities.

\section{Research question}

The primary purpose of this study is to explore the benefits of co-curricular and extra-curricular activities in Telangana Social Welfare Residential Schools. This study decided to address the following research questions:

1. What are the co-curricular and extracurricular activity programs available for students?

2. What are the benefits of co-curricular and extra-curricular activity programs?

3. What is the feedback of students?

\section{Objectives of the study}

The present study aimed to address the following objectives:

1. To explore co-curricular and extra-curricular activity programs available for students.

2. To find out the benefits of co-curricular and extra-curricular activities.

3. To highlight the feedback of students and teachers.

\section{Methodology}

This study adopted Qualitative design, Descriptive and Survey approach and document analysis method, collected data from students, teachers and principals. The study sample selected randomly from the population. Data collected from three sources. They are:

1. Documents available in the schools.

2. Responses collected from 120 principals and teachers with the help of a questionnaire.

3. Feedback from the 300 students with the help of an interview schedule.

\section{RESULTS AND DISCUSSION}

Society residential schools are promoting a unique teaching and learning environment which empowers students. The residential life is very vibrant, and the students benefit from a comprehensive range of curricular, co-curricular and extra-curricular activities hitherto unheard of in the government education sector in India. With technological, innovative and communicative skills playing a more significant role in the future educational prospectus of the students, the Society has introduced many cocurricular and extra-curricular activities programs.

\section{Co-Curricular Activities}

The word co-curricular refers to activities, programs, and learning experiences that complement to curricular activities. TSWREIS schools included many co-curricular activities in the academic calendar in catering to the inner abilities of the student.

\section{Morning Assembly Procedure (15 Minutes)}

The most important consideration of a school assembly is the wholeness, i.e. participation of the whole groups' entire school / senior school / junior school / specific houses like Mercury, Venus, Mars \& Jupiter. A good school assembly program can foster a sense of togetherness. Residential schools introduced a new pattern in conducting the morning assembly to give a chance for more number of students to participate in order to develop leadership skills, communication skills among them. Morning assembly proceeds with Roll Call (Class Wise), Vandemataram, National Pledge, Swaeroes Pledge, Swaero News / Anthem, Talk 
of a Swaero, Talk of the Principal and ends with National Anthem.

Mega Assembly: Mega assembly will be conducted on Monday and Saturday. On Monday the teachers must conduct the Mega Assembly, and on Saturday the School Council must conduct the Mega Assembly. All the students, principal and staff should participate, students should wear the uniform, and principal and staff should also be neatly dressed. The student's talk should be following the themes given in the calendar of events.

House Assembly: On Tuesday and Friday House Assembly should be conducted. All the four houses Mercury, Mars, Venus and Jupiter, should conduct their assemblies separately by choosing suitable places like school ground, school building, in front of the dormitory building, in front of the laboratory building. All the students and in-charge teachers of the respective houses should participate in the assembly. The house captains and their teams must lead the entire assembly with the help of the incharge teachers. The principal, senior and junior vice-principals should monitor the entire assembly procedure of all the four houses.

Class Assembly: On Wednesday and Thursday Class Assembly should be conducted in their respective classrooms duly following the procedure of the morning assembly. The class teachers, along with the class leaders, should lead the assembly.
The school assembly program is fostering a sense of togetherness among students. It has the power to develop and make a positive contribution to student self-development like self-discipline, punctuality, regularity and develops personal and social education as well as moral and cultural development.

\section{Saturday Clubs}

The society schools are conducting Saturday Club activity on every 3rd Saturday from 2:30 pm to 4:30 $\mathrm{pm}$. This time utilized by the students to complete the given task with the help of teachers. These clubs help students to get developed into a wellequipped citizen contributing significantly to the production of a nation. The students gain excellent communication skills, good leadership skills, good presentation skills, excellent coordination skills, good creative skills. All the students must choose one club from each section A and B, so all the students must be a member of 2 clubs, and section $C$ is extra-curricular activities club. In extra-curricular activities club Swatch Saturday is mandatory, all the students must participate in swatch Saturday club. These clubs are helping students in developing unique qualities. They are self-confidence, build respect and learn teamwork, make new friends, relieve stress, learn life skills, learn planning and prioritizing the essential things, thus learning time management skills, and shaping character.

Table 1: Weekly schedule of Morning Assembly activity

\begin{tabular}{|c|c|c|}
\hline Days & Themes & Schedule \\
\hline Monday & Teacher's Talk & $\begin{array}{l}\text { Mega school assembly (headed by principal and the staff.) the } \\
\text { teachers can sing songs, recite the poems, tell a story, demonstrate } \\
\text { an experiment, perform a skit, dance }\end{array}$ \\
\hline Tuesday & $\begin{array}{l}\text { Innovations in STEMS (Science, } \\
\text { Technology, Environment, Math, } \\
\text { Social Sciences.) }\end{array}$ & $\begin{array}{l}\text { House Assembly (headed by the House captains and their team } \\
\text { along with the house in charge teachers) }\end{array}$ \\
\hline Wednesday & $\begin{array}{l}\text { Book review, poem recitation and } \\
\text { storytelling }\end{array}$ & $\begin{array}{l}\text { Class assembly (headed by the class leader, in their classrooms } \\
\text { along with the class teacher }\end{array}$ \\
\hline Thursday & Circle time & $\begin{array}{l}\text { Class assembly. (headed by the class leader, in their classrooms } \\
\text { along with the class teacher) All the students must sit in a circle and } \\
\text { conduct this activity. }\end{array}$ \\
\hline Friday & $\begin{array}{l}\text { Performance activities (songs, } \\
\text { dances, skits, puppetry) }\end{array}$ & $\begin{array}{l}\text { House Assembly ( headed by the House captains and their team } \\
\text { along with the house in charge teachers) }\end{array}$ \\
\hline Saturday & $\begin{array}{l}\text { News reading (covering the week's } \\
\text { news items) }\end{array}$ & $\begin{array}{l}\text { Mega school assembly (headed by school council members) the } \\
\text { members of the school council must read the news covering all the } \\
\text { important news items of that particular week. }\end{array}$ \\
\hline
\end{tabular}


Table 2: Details of Saturday clubs

\begin{tabular}{lll}
\hline $\begin{array}{l}\text { Section A } \\
\text { (Competitions) }\end{array}$ & $\begin{array}{l}\text { Section B } \\
\text { (Co-Curricular Activities Clubs) }\end{array}$ & $\begin{array}{l}\text { Section C } \\
\text { (Extra Curricular Activities Club) }\end{array}$ \\
\hline 1. Ignite Club & $5^{\text {th }}$ to $10^{\text {th }}$ Class & 1. Community Out Reach Program \\
2. All-Go-Rhythm Club & 1. Eco Club & 2. School Garage \\
3. Splash Club & 2. Healthy School Club & 3. School Museum \\
4. Swaero Olympics Club & 3. Good Samariton Club & 4. Kitchen Garden and Compost Making \\
& 4. Entrepreneur Club & 5. Swatch Saturdays (Mandatory) \\
\hline
\end{tabular}

\section{Ignite Club}

This club is meant for co-curricular activities. The activities include Essay Writing, Debate, Quiz, Elocution, Spell Bee, Science fair, Youth parliament (lower classes), Model united nations (higher classes).

\section{Splash Club}

The Splash Club is meant for the talented students in Craft and Artworks. This club programs develop excellent motor skills, increases dexterity, improves hand-eye coordination, encourages self-expression, helps in socializing, boosts self-esteem, promotes innovation and creativity, and enhances decisionmaking skills among the students.

\section{Swaero Olympics}

Residential schools students vied for top honours in many disciplines including athletics, kabaddi, water sports, softball, handball, chess, and martial arts. Students proved their competing spirit by securing gold, silver and bronze medals at international, national and state-level competitions.

Table 3: Sports Achievements 2012-2019

\begin{tabular}{llll}
\hline Participation Level & $\begin{array}{l}\text { Gold } \\
\text { Medals }\end{array}$ & $\begin{array}{l}\text { Silver } \\
\text { Medals }\end{array}$ & $\begin{array}{l}\text { Bronze } \\
\text { Medals }\end{array}$ \\
\hline Inter National Level & 6 & 4 & 8 \\
National Level & 141 & 94 & 92 \\
State Level & 540 & 421 & 292 \\
\hline
\end{tabular}

\section{All-Go-Rhythm}

This club includes all literary and cultural activities like Storytelling, Book review, Movie review, Poetry slam, Handwriting, Dramatic reading, Drama, Songs, Rangoli competition and solo or group classical, folk, tribal dance.

\section{Eco Club}

Eco club is playing a significant role in creating awareness about the environment among the students. It is a platform where we get knowledge about the environment and environment-related issues, problems. The school environment club is the driving force behind all the environmental and sustainable activities at the school. It is organizing, publicizing, promoting and monitoring all environmental sustainable events, activities and problems. It is a wonderful way for young people to develop a sense of ownership, school pride, adding to the community spirit. It gives young students a real sense of responsibility towards the environment.

\section{Healthy School Club}

The Healthy School club is playing a significant role in every part of the school environment from the classroom to the playground. It is promoting healthy eating habits, physical activities, nutrition education, and physical education in order to increase student achievement. This School club supports the health of the students but also helps to boost academic performance. It promotes small activities like brushing teeth, washing hands, eating breakfast every day helps students to remain focused on school and improve their classroom behaviour. This club is organizing awareness program on the importance of physical exercises, yoga and meditation and bringing awareness on different communicable and chronic diseases: Dengue, Malaria, Typhoid, Aids, Swine flu. It is organizing an awareness program on the importance of eating a balance diet, preparing a first aid box and health cards. 


\section{Good Samariton Club}

This club aims at building a new generation with honest, patriotic, liberal and scientific attitude, non-fundamentalist, and strong ethical values. It connects students, parents, teachers, professionals and other important personalities on a platform to discuss and share many issues which affect our lives. This club is conducting guest lectures, organizing workshops, group discussions, dramas, skits and other programs related to the development of ethics and morals. Values are teaching to the students through various activities. Students are learning gratitude, optimism, self-control, grit, social intelligence, zest, curiosity, honesty, punctuality, sharing and caring, cleanliness and gender equality.

\section{Entrepreneur Club}

Teachers explain the importance of the entrepreneur club and the steps in developing a business and give a notion to students how to create a business idea by exploring various problems in the school. Teachers divide the students into groups and give them a starting amount. The students must develop a business idea based on the above mentioned 6 step formulae Creation, Assessment, Planning, Development, Testing, and Launch. Students should choose and take part in entrepreneur activities of making cakes/ cookies/ fruit salad /lemonade, puppet show, jewellery making, selling veggies, sell best out of waste products, photo frames / greeting cards, flower bouquets. This club is helping students to gain knowledge, skills and experience in leadership, communication, group development and management, problem-solving, finance, presentation and public speaking.

\section{Creative Writer's Club}

The Creative Writing Club is an open community of students interested in writing poetry, prose, song lyrics, plays, graphic novels. The purpose of this club is to provide a productive and positive atmosphere for developing student writers to integrate, learn, and grow. Through this club, teachers are encouraging students to write whatever they like without any restrictions, and there are no set rules for writing. The children feel insecure about their spellings, grammatical or structural skills while writing creatively. However, teachers are always focusing on expression. Teachers are allowing students to string words together, supply them with some jumping-off points, like some familiar vocabulary that they need to include in their writing. Students are choosing different types of words, and providing an explanation or discussing those words after the writing.

\section{Language Clubs (E Plus, T Plus, H Plus Clubs)}

Language clubs are providing an opportunity for language learners to practice using languages in a relaxed and friendly setting. This club is making an excellent contribution to student life at a school. Language clubs established to provide a recreational and consolidating opportunity for students to learn and practice English and to create an awareness of themselves as individuals with unique, different talents and capacities. This club aimed to give vent to students' creative talents and to provide an encouraging atmosphere for students to express personal views about the topic given. It is enhancing students' learning opportunities for the topics and students' personality. There are three types of language clubs in the institutions; they are E Plus club (English), T Plus club (Telugu) and $\mathrm{H}$ Plus club (Hindi). Every day teachers are focusing on handwriting practice and dictation in all the languages. Students are learning and practising LSRW skills through various methods like face sheets, dramas, role plays, reading comprehensions, writing stories, watching a movie, and describing people.

\section{STEMS Club}

The word STEMS stands for Science, Technology, Engineering, Mathematics and Social, and it is conducted every week on every Friday from 3.30 $\mathrm{pm}$ to $4.30 \mathrm{pm}$. This club equips students with the knowledge and skills of related subjects. These skills are helping students to learn the theory and practice creating the products associated with daily life. STEMS club is helping students to develop scientific skills, mathematics skills, technology skills, technical skills and socializing skills and enabling them to acquire 21st-century skills that are helping to become global competition citizens.

\section{DEAR Time}

The word DEAR is an acronym that stands for Drop Everything And Read. During this session, 
students should drop what they are doing and read for 20 minutes every Saturday from $12.10 \mathrm{pm}$ to $12.30 \mathrm{pm}$. The students should select a book from their classroom library and read the book for 20mts without getting distracted. Children get exposed to the number of words by merely reading 20 minutes a day. They are picking up and learning new vocabulary. The DEAR time is developing independent reading, and it is imperative for multiple reasons. It is helping to improve student's critical thinking skills, writing skills by making them get exposed to new authors and new books.

\section{DEAP Time}

DEAP stands for Drop Every Thing And Play. This DEAP program is conducted a year thrice. On this day all the students' must-play games. There is a complete play from morning 8:15 am to $4: 30$ $\mathrm{pm}$. This activity is creating a free and healthy atmosphere in the school premises and helping to develop a strong bond among student.

\section{Diary Writing}

Diary writing is an excellent hobby, and it is a very effective strategy for the whole learning process. This activity is for the students of $9^{\text {th }}, 10^{\text {th }}, 1^{\text {st }}$ year and $2^{\text {nd }}$-year class students and they should write every day from $9.00 \mathrm{pm}$ to $9.15 \mathrm{pm}$ under the supervision of Diary leader. Diary writing helps students to improve their writing skills and develops emotional intelligence to manage their emotions better. Diary writing improves communication skills and boosts creativity. Students are advised to write anything about their thoughts, emotions, ideas, feelings, opinions, plans. Writing Diary reflects life experiences and thus helps in making better decisions. Recording thoughts and feelings helps the students to reduce stress, anxiety and overcome hardships as writing is a way of emotional release, and develops a positive mindset.

\section{Healthy Tuesdays}

Residential schools are celebrating every Tuesday as health day in the school. Health nurse, along with the class teacher, should check the health status of the students. The health supervisor visits the allotted class along with the class teacher and checks the health status of the students. They check the health of the students from head to toes and develop a sense of responsibility towards their personal health. They give information on health, illness, illness symptoms, its prevention, first aid medication. During Healthy Tuesday Health nurse develops a personal life long healthy lifestyle plan, including areas of healthy eating, physical exercises, and social relationships.

\section{Mock Trial}

The mock trial is an effective learning tool for elementary and secondary school students. It is helping students to develop useful knowledge about the law, questioning techniques, critical thinking, and oral advocacy skills. Proper mock trials are also leaving student participants with a virtual experience of the difficulties that judges, lawyers and juries face in attempting to present all relevant facts. Residential schools are conducting various types of mock trials. They are (1) Youth Parliament, (2) Mock Election, (3) Moot Courts and (4) Model United Nations.

\section{Extra-Curricular Activities}

Extra-curricular activity is an activity performed by school students, which falls outside the realm of the regular curriculum of school education. Residential schools included extra-curricular activities in the academic calendar to help children to build their skills outside of the classroom. They are School Garage, Community out Reach Programs, Swatch Saturday 3R (Reduce, Reuse, Recycle), Kitchen Garden and Compost Making, School Museum. Every school has the freedom to choose any 2 extra-curricular activities and implement them in the school, and Swacha Saturday is mandatory for every school.

\section{School Garage}

The primary aim of a school garage is to make sure they stand on their feet and make them become responsible and constructive human beings. School Garage is conducted on every 4th Saturday from $3.30 \mathrm{pm}$ to $4.30 \mathrm{pm}$. Residential schools are hiring well-qualified trainers from the local area to train the students in all aspects. This program consists of many activities that are very useful to the children to learn the necessary repairs that are very important in day to day lives. It includes all the activities that concern the person, home, family 
members, community and others. School Garage is a need-based, and professionally oriented activity to assist family and community towards improved living. In the school garage, the trainers are teaching Carpentry, Electronics repairing, Electric repairing, Plumbing works, Wiring, Welding, Stitching, Clay modelling, Interior designing, Beauty care, Best out of waste, Cooking, and Gardening.

\section{Community Outreach Program}

The community outreach program is an activity to identify specific needs in its community and provide services to the people of the community who needs it through various projects and activities. These are practically co-curricular activities for students to enrich learning outside the classroom, including awareness about their community and social environment. The primary objectives of the community outreach program is to prepare students for the transition out of school to the real environment by engaging them with activities and services that will help them acquire life skills and sense of value to become responsible adults. They are (1) Helping Others, (2) Picking Up Litter, (3) Awareness On Traffic Signals, and (4) Planting Trees.

Community outreach programs are most important to students, and they integrate the students with the community. They have much positive influence on the students, helping them to develop skills, social interaction with others and improve the quality of life in themselves and others. These activities are providing a platform for students to apply academic learning to real-life events and helping students to become active members of the community by providing services to those in need. While participating in the activity, students will work together, learn to make decisions and solve problems and thus, they will develop a sense of responsibilities. Students are conducting awareness programs on social issues and needs by performing plays, holding theme-based painting competitions, public speaking activities and forming litter patrol on the school campus and the area. Students are organizing programs for planting trees. Students organize 'kindness week' by helping out the homeless and elders and visiting hospitals with cards.

Swach Saturday: 3 R (Reduce, Reuse and Recycle)
Swach Saturday activity introduced in residential schools to create a healthy atmosphere in the school premises. It is conducted from $5.00 \mathrm{pm}$ to $6.00 \mathrm{pm}$ on Saturdays under the supervision and guidance of special teachers. Students divided into different groups and involve them in cleaning different areas like dormitory, classrooms, playground, dining hall, wellness centre, and library. The Swachh Saturday team should organize this program, and the entire school must participate in this program. The litter warriors should organize skits, dramas, prepare slogans, pamphlets to educate the school about the litter free and green campus program, waste reduction goals, important do's and don'ts of the program. In the $3 \mathrm{R}$ program, students bring awareness on reducing the usage of paper, water and electricity. Under Reuse activity, students make decorative items from used water bottles or ant plastic bottles /rough notebooks from unused papers/ teaching aids and models from used cardboard/ door mats dustbins dusting clothes from used clothes/ watering the plants with wastewater from RO plant. In the Recycling activity, students give importance to the recycling of water, recycling of food wastage and recycling of paper.

\section{Kitchen Garden and Compost Making}

Residential schools are promoting kitchen gardens, and it is a beautiful way to use the schoolyard as a classroom to reconnect students with the natural world. They are helping in teaching children the real source of the food they eat, teach them valuable gardening and agricultural concepts and skills that integrate with classroom subjects such as math, social, science, languages, as well as several educational goals that include personal and social responsibility. Benefits of the kitchen garden are the schoolyard is diversified and beautified, graffiti and vandalism decrease. It is a creative and a delightful hobby is developed which lasts throughout life. Kitchen garden develops focus, patience, cooperation, teamwork, social skills among students and develops self-confidence, a sense of responsibility. Residential schools are giving importance to the making of school compost. Compost is decomposed organic matter that can be used as a fertilizer. It is very beneficial for plants because it is rich in nutrients, and it can be applied to soil as an amendment or plants in several 
ways. This activity reduces the need for chemical utilization, making it a key component in organic farming.

\section{School Museum}

The School Museum activity is offering a holistic education including academic knowledge, expression and debating skills, life skills, performing art skills and vocational skills. This program is helping in exposing the students to a whole world of knowledge of different types of subject issues, space, sports, animals, books, earth, plants, and influential personalities. Teachers are developing curiosity in the children mind by encouraging them to go round the museum every day, and they are encouraged to identify the exhibit for the topic. The school museum includes many things. They are School history, Achievements of the school and staff, Achievement of the students and alumni, Student projects, Portraits of different cultures of the World/ India/ Telangana, Wonders of the world, Modals of different civilizations of the world, Chronology of different kings and kingdoms, Earth, the interior of the earth, domains of the earth, landforms of the earth, space and other related objects of the space working modals of different unique objects, satellites, Sports and sports personalities, Different calamities, Important symbols, collection of different coins, currencies, flags, and Important personalities.

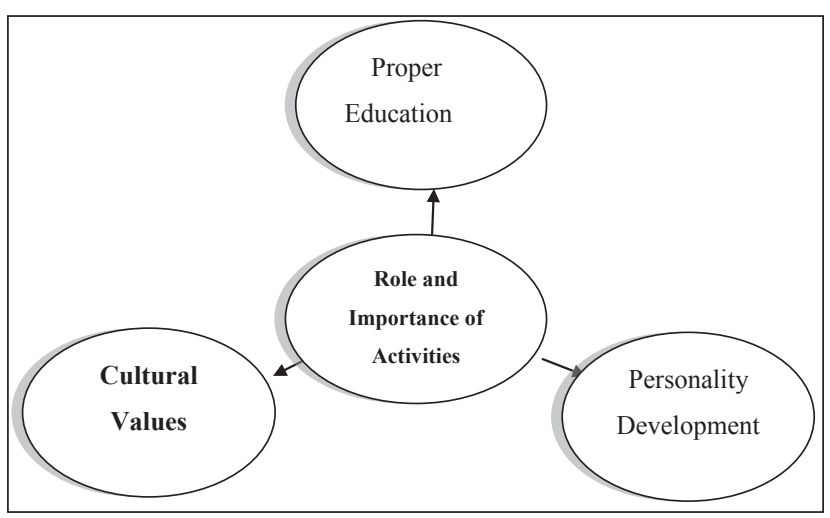

Fig. 1: Role of Co-curricular and extra-curricular activities

\section{CONCLUSION}

The students through co-curricular activities train essential ethical values about different religions, events, cultures of national and international importance as well as discipline and school life ethics. They learn to understand different religions, patience, empathy, values, social ethics, motivational skills, compatibility and contentment.

\section{REFERENCES}

Abreo, A.J. 2003. Co curricular activities in different types of secondary schools of Goa: A study. INFLIBNET. http:// shodhganga.inflibnet.ac.in:8080/jspui/handle/10603/31797

Behtoui, A. 2019. Swedish Young People's After-School Extracurricular Activities: Attendance, Opportunities and Consequences. British Journal of Sociology of Education, 40(3): 340-356.

Clariana, M., Cladellas, R., Gotzens, C., Badia, M. and Dezcallar, T. 2014. Typology of Extra-curricular Activities and Academic Procrastination among Primary Education Students. Electronic Journal of Research in Educational Psychology, 12(2): 419-445.

Dikshit, D.K. 2017. A study of association of Co Curricular activities with academic achievement and inculcation of moral values in students of secondary school of Dhandbad Jharkhand. University. http://shodhganga.inflibnet. ac.in:8080/jspui/handle/10603/245238

Eraiah, D. 2016. Attitude towards co curricular activities self concept and academic achievement among students of standard $\mathrm{XI}^{\text {th }}$ in residential and non residential schools a comparative study. University. http://shodhganga. inflibnet.ac.in:8080/jspui/handle/10603/153018

Prakash, G.A.P. 2008. Co-Curricular activities-attitude and participation of secondary school students. University. http://shodhganga.inflibnet.ac.in:8080/jspui/ handle/10603/127111

Siddiky, M.R. 2019. Developing Co-Curricular Activities And Extra-curricular Activities for All-Round Development of the Undergraduate Students: A Study of a Selected Public University in Bangladesh. Pakistan Journal of Applied Social Sciences, 10(1): 61-82.

Simoncini, K. and Caltabiono, N. 2012. Young School-Aged Children's Behaviour and Their Participation in Extracurricular Activities. Australasian Journal of Early Childhood, 37(3): 35-42.

TGSWREIS. (n.d.). Retrieved August 9, 2020, from http://182.18.156.61/tgswfproduct1/loginswf.jsp

TSWREIS. (n.d.). Retrieved August 9, 2020, from https:// tswreis.in/index-2.html 
